\title{
Thermal Balancing of a Multi-Cylinder Diesel Engine Operating on Diesel, B5 and Palm Biodiesel Blends
}

\author{
M. J. Abedin, H. H. Masjuki, M. A. Kalam, A. Sanjid, and S. M. A. Rahman
}

\begin{abstract}
Energy crisis and global warming are the two most important issues that threaten the peaceful existence of the human species. More dependency on alternative fuels and energy loss minimization can be an effective solution to this affair. In this regard, thermal balance study of an internal combustion (IC) engine using different biodiesels is worthy of investigation. This manuscript provides an in-depth analysis of the engine heat losses in different subsystems of the engine. Finally, thermal balancing of the engine has been done by showing all energy flows in and out of the engine. The investigation was conducted in a four cylinder diesel engine fuelled with pure diesel, B5 (5\% Palm biodiesel $+95 \%$ Diesel), $10 \%$ (PB10) and $20 \%$ (PB20) palm biodiesel blends at full load and in the speed range 1000 to 4000 RPM. The water heat loss and lubricating oil heat loss increased whereas the engine brake power, exhaust heat loss and unaccounted heat loss decreased with the increase of biodiesel percentage in the blends.
\end{abstract}

Index Terms-Thermal balance, heat loss, palm biodiesel, diesel engine.

\section{INTRODUCTION}

The fast depletion of fossil fuels, the alarming rate at which the Earth's atmosphere is getting polluted, the increased impact of global warming on Earth and the stringent anti-pollution laws imposed in certain countries have created a stimulus to explore and evaluate alternative fuels for IC engines. Nowadays, biodiesel is considered the most promising alternative fuel by the researchers due to its comparable properties with diesel fuel and also other socio-economic and environmental benefits [1], [2]. Another major advantage of biodiesel is, it can be blended with diesel fuel at any proportions and can be used in the diesel engines without further modifications [3]-[5].

IC engines can be considered as thermodynamic 'open system', which is a powerful concept to understand the thermodynamic behavior of a system. It is linked to the idea of 'control volume', a space enclosing the system and surrounded by an imaginary surface often known as 'control surface'.

The advantage of this concept is that once one has identified all the energy and mass flows into and out of a system, it is very easy to visualize the inside picture of that system by drawing a thermal balance sheet of the inflows and outflows [6]. It is basically an analysis of the first law of

Manuscript received January 2, 2014; revised May 28, 2014.

M. J. Abedin, H. H. Masjuki, M. A. Kalam, A. Sanjid, and S. M. A. Rahman are with Centre for Energy Sciences, Faculty of Engineering, University of Malaya, 50603 Kuala Lumpur, Malaysia (e-mail address: joynu106me@yahoo.com). thermodynamics which is also known as energy balance or heat balance.

Thermal balancing has been done by using different alternative fuels such as $\mathrm{H}_{2}$-gasoline [7], alcohol-diesel [8]. Biodiesels such as soybean, yellow grease also have been used for thermal balancing [9]. They have reported that all the heat losses except exhaust heat loss were higher while using biodiesels rather than diesel fuel. $\mathrm{H}_{2}$ with gasoline, reduced brake power and cooling water loss while the exhaust loss was almost same. Ethanol-diesel blends showed higher brake power and lower heat loss compared to pure diesel fuel.

The objective of this article is to find out all heat losses in different sub-systems of the engine and finally to draw a thermal balance sheet using diesel, B5, 10\%, and 20\% Palm biodiesel blends.

\section{MethodOLOGY}

The experiment was conducted in a four-cylinder Mitsubishi diesel engine. The engine specifications are provided in Table I.

\begin{tabular}{|c|c|} 
TABLE I: SPECIFICATIONS OF THE TESTED ENGINE \\
\begin{tabular}{|c|c|}
\hline Parameter & Specification \\
\hline Engine type & Inline four cylinder SOHC \\
\hline Bore & $91.1 \mathrm{~mm}$ \\
\hline Stroke & $95.0 \mathrm{~mm}$ \\
\hline Displacement & $2.5 \mathrm{~L}(2476 \mathrm{cc})$ \\
\hline Compression ratio & $21: 1$ \\
\hline Power & $55 \mathrm{~kW}$ at $4200 \mathrm{rpm}$ \\
\hline Torque & $142 \mathrm{Nm}$ at $2500 \mathrm{rpm}$ \\
\hline Fuel injection system & Distribution type jet pump \\
\hline
\end{tabular}
\end{tabular}

The engine was operated at full load and in the speed range 1000 to 4000 RPM. It was coupled with a water cooled passive eddy current dynamometer. REO-dCA software has been used as engine test bed controller and data acquisition system. Eight K-type thermocouples have been used in different positions of the engine to collect temperature data and Rotameter has been used for flow measurement. In our experiment, we have tested $10 \%$ and $20 \%$ blends of Palm biodiesel along with diesel and B5 fuel. Crude Palm oil was provided by Forest Research Institute Malaysia (FRIM). Diesel and B5 biodiesel were bought by the authors from a BHPetrol oil filling station near the University of Malaya. The oils were converted to the biodiesel, and the properties were measured at the Department of Mechanical Engineering, University of Malaya, Malaysia. The measured fuel properties are listed in Table II. 
TABLE II: FUEL PROPERTIES OF ALL THE TESTED BLENDS

\begin{tabular}{|l|l|l|l|l|l|l|}
\hline Properties & Diesel & B5 & PB10 & PB20 & Testing equipment & Test Method and Specification Limits \\
\hline Density at $15^{0} \mathrm{C}\left(\mathrm{kg} / \mathrm{m}^{3}\right)$ & 830.5 & 834.2 & 838 & 849.5 & SVM 3000 (Anton Paar, UK) & ASTM D4052 \\
\hline Calorific Value $(\mathrm{MJ} / \mathrm{kg})$ & 44.7 & 41.3 & 40.5 & 40.1 & C2000 basic calorimeter (IKA, UK) & ASTM D240 \\
\hline Viscosity at $40^{\circ} \mathrm{C}(\mathrm{cSt})$ & 3.610 & 3.905 & 4.031 & 4.183 & SVM 3000 (Anton Paar, UK) & ASTM D445 (1.9-6.0) \\
\hline
\end{tabular}

\section{HEAT LOSS CALCULATION}

The steady flow first law of thermodynamics for an IC engine will be [2]

$$
Q_{s}=P_{b}+Q_{w}+Q_{e x h}+Q_{o i l}+Q_{u n}
$$

where $\left(Q_{s}\right)$ is the supplied fuel energy and given by

$$
Q_{s}=\dot{m}_{f} \times Q_{L H V}
$$

$m_{f}$ and $Q_{L H V}$ are the mass flue rate and calorific value of fuel, respectively.

Engine brake power $\left(P_{b}\right)$ is given by the equation

$$
P_{b}=2 \times \pi \times N(\mathrm{rev} / \mathrm{s}) \times T(N . \mathrm{m}) \times 10^{-3}
$$

where $N$ and $T$ are the engine RPM and torque, respectively.

The cooling water heat loss $\left(Q_{w}\right)$ is

$$
Q_{w}=\dot{m}_{w} \times C_{w} \times \Delta T_{w}
$$

where $m_{w}, C_{w}$ are mass flow rate and specific heat of water and $\Delta T_{w}$ is temperature difference between water inlet and outlet.

If the required heat to raise the temperature of total mass (air + fuel) with respect to outside ambient air temperature $\left(T_{a}\right)$ to exhaust gas temperature $\left(T_{g}\right)$ is known, one can measure the exhaust heat loss $\left(Q_{\text {exh }}\right)$.

$$
Q_{e x h}=\left(\dot{m}_{f}+\dot{m}_{a}\right) \times C_{g} \times\left(T_{g}-T_{a}\right)
$$

The amount of heat carried away by the lubricating oil $\left(Q_{\text {oil }}\right)$ can be calculated from this equation

$$
Q_{o i l}=\dot{m}_{o i l} \times C_{o i l} \times \Delta T_{o i l}
$$

where $m_{\text {oil }}, C_{\text {oil }}$ are mass flow rate and specific heat of lubricating oil and $\Delta T_{\text {oil }}$ is temperature difference between lubricating oil inlet and outlet.

Finally, the unaccounted heat loss $\left(Q_{u n}\right)$ is

$$
Q_{u n}=Q_{s}-\left(P_{b}+Q_{w}+Q_{e x h}+Q_{o i l}\right)
$$

\section{RESUlTS AND DisCUSSION}

The supplied energy $\left(Q_{s}\right)$ is the amount fuel entering into the combustion chamber multiplied by its calorific value (Fig. 1). Biodiesels have higher density and lower calorific value. Supplied energy is the higher for high calorific fuel and lower for low calorific fuel. As the RPM increases more fuel is required to burn in the combustion chamber, hence the supplied energy increases.

From Fig. 2 and Fig. 3, it is clear that the water heat loss $\left(Q_{w}\right)$ and lubricating oil heat loss $\left(Q_{\text {oil }}\right)$ is higher while using biodiesels because biodiesels promote better fuel combustion. The water heat loss was increased about $1 \%$ to $3 \%$ and the lubricating oil heat loss was increased about $1 \%$ to $2 \%$ for $5 \%$ to $10 \%$ biodiesel addition with fossil diesel.

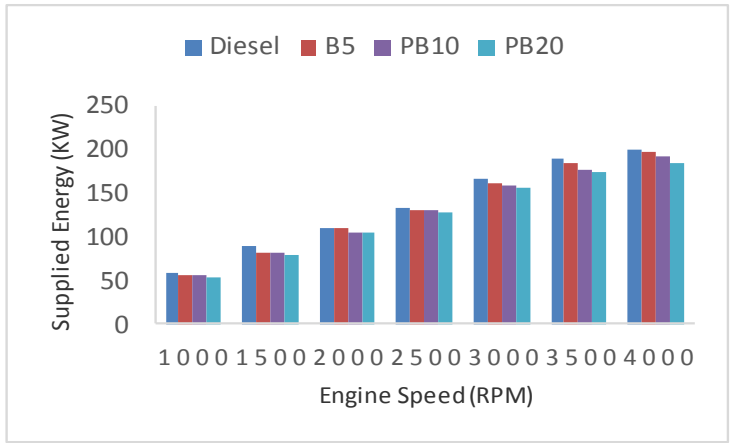

Fig. 1. Variation of supplied fuel energy.

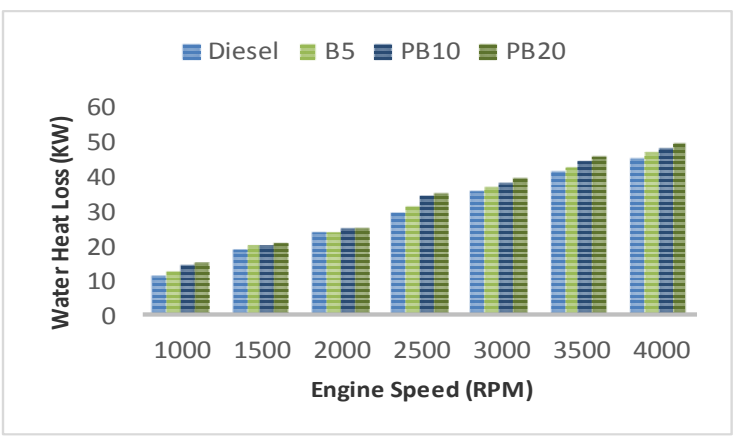

Fig. 2. Water heat loss variation with engine speed.

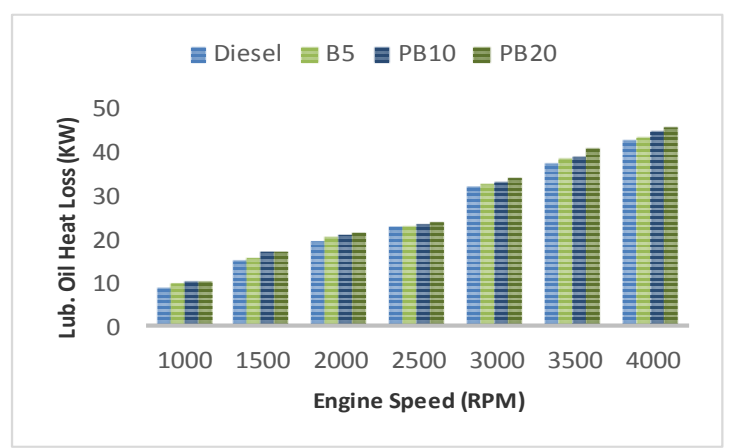

Fig. 3. Lubricating Oil heat loss characteristics

From Fig. 4, it is clear that diesel fuel exhibits the highest exhaust heat loss $\left(Q_{e x h}\right)$ compared to biodiesel blends. It can be attributed to the high concentration of $\mathrm{HC}$ and $\mathrm{CO}$ emissions associated with diesel fuel.

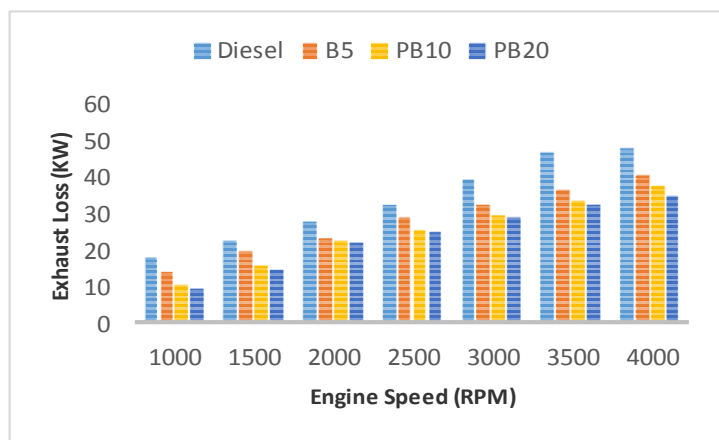

Fig. 4. Exhaust heat loss variation. 


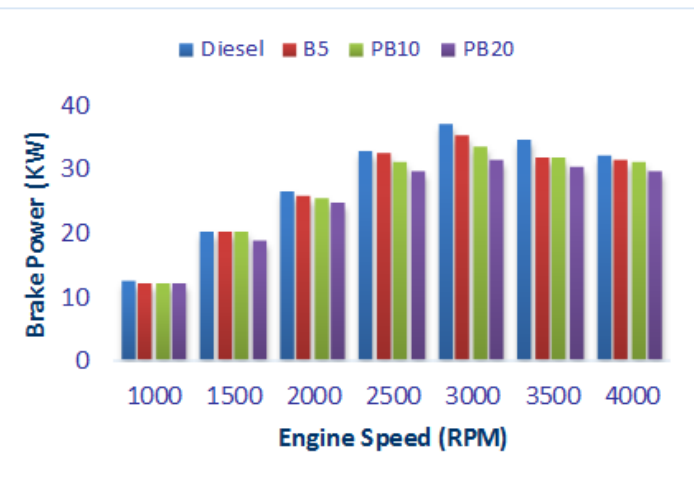

Fig. 5. Brake power variations of all the tested blends.

The usable power delivered by an engine is known as brake power $\left(P_{b}\right)$. This is the final output power of the engine, which is the product of engine torque and angular speed (Equation 3 ). Fig. 5 shows the variations in brake power of all the tested blends. It is clear that the brake power is slightly decreased for biodiesel addition with fossil diesel fuel. The reasons behind lower brake power are attributed to the lower calorific value and higher viscosity of biodiesel compared to fossil diesel. Biodiesel has higher oxygen content, which lowers the calorific value. Having lower calorific value and higher viscosity cause uneven combustion, hence lower brake power.

Thermal balancing is shown for all the tested fuels in Fig. 6 at 3000 RPM.

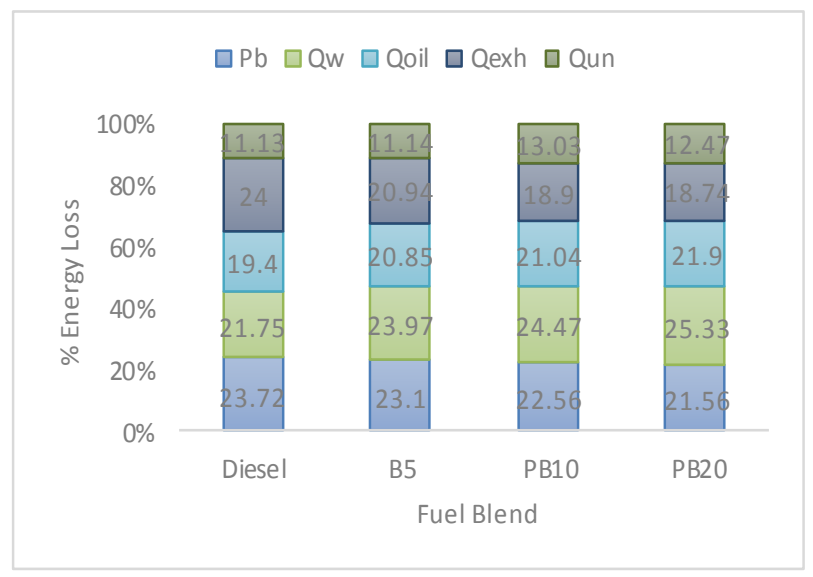

Fig. 6. Thermal balancing at 3000 RPM.

From Fig. 6, 22.56\% of the supplied energy is converted to useful work, $24.47 \%$ is lost through the cooling water, $21.04 \%$ is lost with the lubricating oil, and $18.9 \%$ is lost with the exhaust. If we compare this with PB20 at 3000 RPM, the brake power is slightly decreased, the cooling water heat loss and lubricating oil heat loss also increased while the exhaust loss and the unaccounted heat loss decreased. And for diesel fuel, it is found that $23.72 \%$ of the supplied fuel energy was converted to brake power, due to its higher calorific value and lower viscosity compared to all other blends. Similar trend is observed for the other blends at different speeds. The unaccounted heat loss $\left(Q_{u n}\right)$ was computed by subtracting the summation of all heat losses from the supplied fuel energy. It covers mostly the convection and radiation heat losses from the cylinder walls and also other unknown heat losses from the engine. The trend of this heat loss is not definite.

\section{CONCLUSION}

The brake power is slightly decreased with the addition of biodiesel percentage. Peak combustion temperature associated with the biodiesels helped to increase water heat loss and lubrication oil heat loss. The exhaust heat loss was decreased with the addition of biodiesel. If the heat losses from the engine can be reduced, the brake power of the biodiesel fueled engine will increase. In conclusion, biodiesel can be used up to $20 \%$ without major modification of the engine.

\section{ACKNOWLEDGMENT}

The authors would like to acknowledge University of Malaya for financial support through High Impact Research Grant UM.C/HIR/MOHE/ENG/07.

\section{REFERENCES}

[1] S. M. A. Rahman, H. H. Masjuki, M. A. Kalam, M. J. Abedin, A Sanjid, and H. Sajjad, "Production of palm and Calophyllum inophyllum based biodiesel and investigation of blend performance and exhaust emission in an unmodified diesel engine at high idling conditions," Energy Conversion and Management, vol. 76, pp. 362-367, 2013.

[2] A. Sanjid, H. H. Masjuki, M. A. Kalam, S. M. A. Rahman, M. J. Abedin, and S. M. Palash, "Impact of palm, mustard, waste cooking oil and Calophyllum inophyllum biofuels on performance and emission of CI engine," Renewable and Sustainable Energy Reviews, vol. 27, pp. 664-82, 2013.

[3] A. Sanjid, H. H. Masjuki, M. A. Kalam, S. M. A. Rahman, M. J. Abedin, and S. M. Palash, "Production of palm and jatropha based biodiesel and investigation of palm-jatropha combined blend properties, performance, exhaust emission and noise in an unmodified diesel engine," Journal of Cleaner Production, 2013.

[4] S. M. Palash, H. H. Masjuki, M. A. Kalam, B. M. Masum, A. Sanjid, and M. J. Abedin, "State of the art of NO $x$ mitigation technologies and their effect on the performance and emission characteristics of biodiesel-fueled Compression Ignition engines," Energy Conversion and Management, vol. 76, pp. 400-20, 2013.

[5] S. M. A. Rahman, H. H. Masjuki, M. A. Kalam, M. J. Abedin, A. Sanjid, and S. Imtenan, "Effect of idling on fuel consumption and emissions of a diesel engine fuelled by Jatropha biodiesel blends," Journal of Cleaner Production, 2014.

[6] M. J. Abedin, H. H. Masjuki, M. A. Kalam, A. Sanjid, S. M. A. Rahman, and B. M. Masum, "Energy balance of internal combustion engines using alternative fuels," Renewable and Sustainable Energy Reviews, vol. 26, pp. 20-33, 2013.

[7] F. Yüksel and M. A. Ceviz, "Thermal balance of a four stroke SI engine operating on hydrogen as a supplementary fuel," Energy, vol. 28, no. 11, pp. 1069-1080, 2003.

[8] E. A. Ajav, B. Singh, and T. K. Bhattacharya, "Thermal balance of a single cylinder diesel engine operating on alternative fuels," Energy Conversion and Management, vol. 41, no. 14, pp. 1533-1541, 2000.

[9] M. Canakci and M. Hosoz, "Energy and exergy analyses of a diesel engine fuelled with various biodiesels," Energy Sources, Part B, vol. 1, no. 4 , pp. $379-394,2006$.

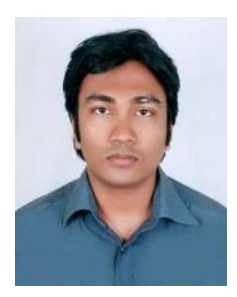

M. J. Abedin received his B.Sc. degree in mechanical engineering from Bangladesh University of Engineering and Technology (BUET), Bangladesh, in 2012.

He is now a master's candidate in the Department of Mechanical Engineering at University of Malaya, Kuala Lumpur, Malaysia. He is also working as a research assistant in the Centre for Energy Sciences Laboratory. His current research interests include biodiesel property measurement, engine heat transfer analysis, diesel engine combustion, performance, and emission analysis using biodiesel. 


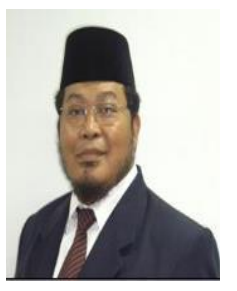

H. H. Masjuki obtained his mechanical engineering degree (B.Sc.), at Leeds University, Leeds U.K. in 1977.

He continued to pursue his M.Sc. in tribology and $\mathrm{Ph} . \mathrm{D}$. from the same university and graduated in 1978 and 1982 respectively. Upon the completion of his studies, he was being appointed as a lecturer in 1983 at University of Malaya. He is currently appointed as the professor at Mechanical Engineering Department, University of Malaya. He is also one of the senate members of University of Malaya and secretary of Council of National Professors- Engineering and Technology cluster.

$\mathrm{He}$ is the founding president of Malaysian Tribology Society (MyTRIBOS) and the Director of the Centre for Energy Sciences.

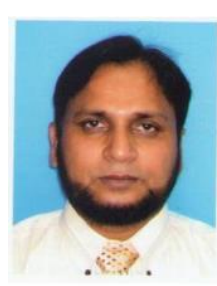

M. A. Kalam received his B.Sc. degree in mechanical engineering from Khulna University of Engineering and Technology (KUET), Bangladesh. He earned his masters and $\mathrm{PhD}$ degree from University of Malaya, Malaysia.

He is now a senior lecturer in the Department of Mechanical Engineering at University of Malaya. He is an expert in combustion and fuel engineering (Internal combustion engine, Biofuel, Bio-lubricant, NGV, Exhaust Emission, and HCCI and EGR system.)

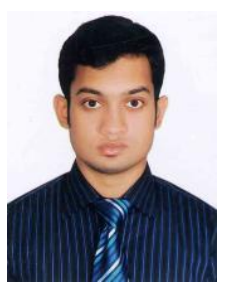

A. Sanjid received his B.Sc. degree in mechanical engineering from Bangladesh University of Engineering and Technology (BUET), Bangladesh, in 2012.

He is now a master's candidate in the Department of Mechanical Engineering at University of Malaya, Malaysia. He is particularly interested in the application of biodiesel in diesel engine.

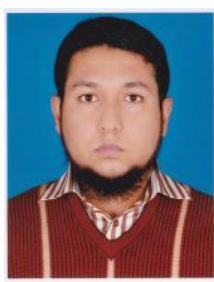

S. M. Ashrafur Rahman received his B.Sc. degree in mechanical engineering from Bangladesh University of Engineering and Technology (BUET), Bangladesh, in 2012 .

He is now a master's candidate in the Department of Mechanical Engineering at University of Malaya, Malaysia. 